\title{
Value, Support, and Advancement: An Organization's Role in Faculty Career Intentions in Academic Medicine
}

\author{
Fátima Sancheznieto (D) \\ Angela Byars-Winston ${ }^{1,2}$ \\ 'Collaborative Center for Health Equity, \\ School of Medicine and Public Health, \\ University of Wisconsin - Madison, \\ Madison, WI, USA; ${ }^{2}$ Department of \\ Medicine, School of Medicine and Public \\ Health, University of Wisconsin - \\ Madison, Madison, WI, USA
}

Purpose: Faculty engagement in academic medical centers is essential to advancing efficient healthcare delivery, research productivity, and organizational quality. The authors used turnover theory to empirically examine factors that influence faculty engagement, including both aspirational and attrition-related career intentions.

Methods: Using a convergent, mixed methods design, the authors surveyed 284 faculty at a large Midwestern public university's school of medicine in Fall 2015, Fall 2016, and Spring 2017. The study's questionnaire included a series of scales which informed three outcome variables (promotion aspirations, leadership aspirations, and intent to leave the organization) and four groups (role strain, work-family conflict, organizational commitment and support, and departmental commitment and support) of predictor variables, all of which have been previously validated with medical faculty populations. The scales were followed by open-ended questions which allowed respondents to further elaborate on their experiences in their organization related to each outcome variable. The authors used a hierarchical multiple regression model to assess the effect of each of the four groups of predictor variables on the outcome variables and then employed an iterative thematic analysis of openended responses to further elucidate faculty's reported experiences.

Results: Organizational commitment and support were significantly associated with faculty's promotion aspirations, leadership aspirations, and intentions to leave the organization. Thematic analysis of participant responses to open-ended questions further revealed the specific career development support faculty desired, mainly, streamlined and transparent promotion and leadership processes; clear guidance to maneuver these processes; holistic professional development opportunities; feeling valued; and supports for clinical and administrative tasks.

Conclusion: Advancing organizational policy that supports infrastructure for evidencebased interventions and programming for the intentional career development of faculty is an important aspect of a proactive talent development and retention model in academic medical centers.

Keywords: faculty retention, academic medicine, career development, organizational support, turnover theory

\section{Introduction}

Faculty are a vital human resource in academic medical centers. Executive leadership in academic medicine relies on their faculty to be engaged in advancing efficient healthcare delivery, conducting research and making scientific discoveries, and educating future physicians and scientists. ${ }^{1,2}$ Faculty face a myriad of
Institute for Clinical and Translationa Research, 2112 Health Sciences Learning Center, 750 Highland Avenue, Madison, WI, 53705, USA

Tel + I 608 263-1018

Email ruiz9@wisc.edu 
challenges however, that can compromise their career intentions, including dwindling research support and significant changes in healthcare delivery and funding. ${ }^{2}$ A study conducted for the Association of American Medical Colleges (AAMC) revealed that leadership may believe that their faculty are thriving and have the infrastructure they need to be successful, while faculty actually feel lost in navigating institutional processes and feel unable to adequately perform their jobs. ${ }^{3}$ This study also revealed specific challenges for female faculty and those from underrepresented racial/ethnic groups in advancement and retention. Challenges with navigating institutional processes and feeling inadequate at work are associated with job dissatisfaction and professional burnout, both of which may eventually lead to job turnover. ${ }^{1,2,4}$

Turnover represents people changing jobs within an organization or leaving an organization within a given year.${ }^{5}$ Turnover theory, backed by many decades of research, ${ }^{5}$ reveals that on-the-job and off-the-job constructs influence turnover intentions. On-the-job constructs include factors like role clarity and perceived support from and commitment to one's organization. Individuals with low role strain, high organizational commitment, and favorable organizational support have reported lower intentions to leave their environment. ${ }^{6}$ Off-the-job constructs include factors like expectations for one's life and work roles, which can be in conflict. Frone et $\mathrm{al}^{7}$ specified two types of conflict: work interfering with family and family interfering with work. A recent survey of academic medical faculty revealed that both men and women had comparatively greater work into family conflicts than family into work conflicts overall, with women reporting slightly higher rates of conflict in both domains. ${ }^{8}$

Examining on-the-job and off-the-job factors can help inform evidence-based approaches to developing and retaining talent needed for executive leaders to promote faculty engagement in academic medicine. Because turnover research focuses on attrition outcomes like intention to change or leave one's job, there is more to learn about correlates of aspirational outcomes for faculty like seeking promotion and advancement in their organization. A prior study investigated correlates of seeking promotion and advancement (aspiration) and intention to leave (attrition) at one large, private medical college with no time restrictions to the promotion and tenure clock and found several gender differences. ${ }^{9}$ Women had lower promotion and advancement seeking than men and work to family conflict negatively predicted women's leadership seeking. We need to know more about aspiration and attrition career intentions of both men and women at different types of institutions, like those that require tenure and promotion with time restrictions. Examining faculty career intentions provides executive leaders with data to tailor their talent management systems to faculty needs and benchmarking data against which to gauge the effectiveness of those systems. Results from the AAMC program mentioned earlier confirmed that academic medical centers that implemented and sustained well-designed talent management systems had substantial improvements to individual and organizational performance as well as higher levels of employee satisfaction, engagement, and retention. ${ }^{3}$

The objective of this exploratory study was to identify factors that contribute to aspirational and attrition-related faculty career intentions in academic medicine. We tested a conceptual model based on turnover theory ${ }^{5}$ at one public university with promotion and tenure time restrictions to identify factors that influence three dependent variables: seeking promotion, seeking leadership, and intentions to leave their institution. Using data from a faculty survey, we examined the workplace perceptions of faculty participants to identify organizational factors that may guide academic medicine leadership in creating talent development strategies.

\section{Materials and Methods Convergent Mixed Methods: Questionnaire Variant}

Our study followed a convergent, mixed methods design in which quantitative data and follow-up qualitative shortanswer responses were collected in the same survey. Though supplemental to the quantitative data, this exploration of the qualitative data can uncover underlying faculty experiences and common patterns that quantitative analyses cannot. Because the qualitative component of the survey supplements the quantitative component, as opposed to being an independent process of data collection and analysis, this questionnaire variant of convergent mixed methods has previously been referred to as "mixed methods light". ${ }^{10}$

\section{Survey Design: Quantitative}

We measured four groups of predictor variables, three outcome variables, and participant demographics using a theoretically derived and validated survey previously used to examine the career motivations of faculty at a different large academic medical center. ${ }^{9}$ The 
demographic variables included Gender, Race, and Ethnicity, given trends in AAMC surveys of disparate career outcomes by these demographic groups, ${ }^{3}$ and whether the respondent had Children, as they may contribute to work-family conflict. ${ }^{11}$ We also included faculty Rank as a positional resource with varying levels of autonomy and job security from junior to senior rank ${ }^{10}$ and faculty Track given the varying job expectations for clinical and research duties. We surveyed four groups of predictor variables (Role Strain, Work-Family Conflict, Organizational Commitment and Support, and Departmental Commitment and Support) and measured Promotion Aspirations, Leadership Aspirations, and Intentions to Leave the organization as career intention outcome variables. Participants rated their level of agreement with items on a Likert-type scale ranging from 1 (strongly disagree) to 5 (strongly agree). Mean responses to scale questions were calculated such that higher scores indicate more of that construct. The complete list of scales and constructs and the inter-item reliability values, as well as kurtosis and skewness for each mean scale score can be found in Table 1 and Supplementary List 1.

\section{Survey Design: Qualitative}

Our short answer questions allowed capture of respondents' experiences of the three outcome variables in their own words. Questions can be found in Supplementary List 2.

\section{Data Collection: Quantitative and Qualitative}

We obtained a list of full-time faculty at the school of medicine study site through the Office of the Associate Dean for Research. This list included approximately 1523 faculty between fall 2015 and fall 2016 from the three faculty tracks: full time clinical, full time research, and a hybrid track that combines clinical with clinical teaching or research duties, as is found in many academic medical centers. The email invitation originated in and was distributed by the dean's office with the anonymized survey administered through Qualtrics. Three follow-up reminder emails were sent in each semester that the survey was conducted, between one and three weeks apart. Two dozen additional responses were received in Spring 2017 after a campus presentation by one of the authors. A total of 377 responses were collected, representing a $25 \%$ response rate.
Table I Scale Inter-Item Reliability and Means Scale Score Normality

\begin{tabular}{|c|c|c|c|}
\hline & $\alpha^{\mathbf{a}}$ & Skewness $^{\text {b }}$ & Kurtosis \\
\hline \multicolumn{4}{|l|}{ Role Strain } \\
\hline Role Certainty & 0.908 & -0.719 & 0.413 \\
\hline Role Conflict & 0.732 & 0 & -0.574 \\
\hline Role Overload & 0.926 & -0.319 & -0.395 \\
\hline \multicolumn{4}{|l|}{ Work-Family Conflict } \\
\hline Multiple Role Flexibility & 0.753 & -0.392 & -0.375 \\
\hline Work into Family Conflict & 0.923 & -0.773 & 0.722 \\
\hline Family into Work Conflict & 0.911 & 0.396 & -0.225 \\
\hline \multicolumn{4}{|l|}{ Organizational } \\
\hline \multicolumn{4}{|l|}{ Commitment and } \\
\hline \multicolumn{4}{|l|}{ Support } \\
\hline Commitment to the & 0.909 & -0.097 & -0.335 \\
\hline \multicolumn{4}{|l|}{ Organization } \\
\hline Support from the & 0.956 & 0.123 & -0.328 \\
\hline \multicolumn{4}{|l|}{ Organization } \\
\hline \multirow{3}{*}{\multicolumn{4}{|c|}{$\begin{array}{l}\text { Departmental } \\
\text { Commitment and } \\
\text { Support }\end{array}$}} \\
\hline & & & \\
\hline & & & \\
\hline Commitment to the & 0.918 & -0.538 & -0.232 \\
\hline \multicolumn{4}{|l|}{ Department } \\
\hline Support from the & 0.964 & -0.503 & -0.676 \\
\hline \multicolumn{4}{|l|}{ Department } \\
\hline Promotion Climate & 0.919 & -0.242 & -0.349 \\
\hline \multicolumn{4}{|l|}{ Outcome Variables } \\
\hline Leadership Aspirations & 0.774 & -0.333 & -0.444 \\
\hline Promotion Aspirations & Single Question & -0.558 & -0.827 \\
\hline Intentions to Leave & Single Question & 0.776 & -0.392 \\
\hline
\end{tabular}

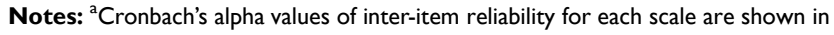
the first column. Note that two of the outcome variables were measured using a single item. ${ }^{b}$ Kurtosis and skewness values for the distribution of mean scale scores for all cases. All values fall within $-\mathrm{I}$ and $\mathrm{I}$.

\section{Data Analysis: Quantitative}

We used IBM SPSS software version 25 for all statistical analyses. Because most of the missing data appeared to be due to survey drop-out, we ran Little's Missing Completely at Random (MCAR) Test, for which the $p$ value was 0.717 , indicating randomness to our missing data. ${ }^{12}$ We next deleted any cases for which participants dropped out before responding to the outcome variable questions. A total of 291 cases were retained. Four respondents chose not to report their gender, and three selected to report their gender as Other. We kept these cases for qualitative analysis but removed them for statistical analysis based on binary gender, leaving a total of 284 cases for quantitative analysis. Following reverse scoring for appropriate questions within a variable's scale, we calculated mean scale scores for cases that had answered $75 \%$ or more of a variable's scale. We discarded cases for 
specific variables which had lower response percentages within a scale. All variables had absolute values for kurtosis and skewness that were lower than 1 and were found to be normally distributed using the Kolmogorov-Smirnov test for normality with the Lilliefors Significance Correction. ${ }^{13}$ Bivariate correlations for all variables can be found in Supplementary Table 1.

To determine how groups of predictor variables affected variance in the outcome variables, we developed a hierarchical multiple regression model in which we added variables in a total of five steps corresponding to their variable group: Step 1 - Demographics (Gender, Track, Rank, Children); Step 2 - Role Strain (Role Certainty, Role Conflict, Role Overload); Step 3 - WorkFamily Conflict (Multiple Role Flexibility, Work into Family conflict, Family into Work conflict); Step 4 Organizational Commitment and Support (Commitment to the Organization, Support from the Organization); Step 5 - Departmental Commitment and Support (Commitment to the Department, Support from the Department, Promotion Climate equity). We considered a rejection of the null hypothesis for any statistical test significant for $p$ values below 0.05 , denoted by an asterisk and marked in bold. We denote $P$ values below 0.01 with two asterisks.

\section{Data Analysis: Qualitative}

We used NVivo 12 Pro as an organizational tool for data coding and memo-writing in our qualitative analysis. Because we did not develop new theoretical frameworks grounded solely in the qualitative data, ${ }^{14}$ we do not describe our two-stage coding process as grounded theory, though we relied on its methodological principles to further understand faculty's motivations for seeking promotion and leadership and their intentions to leave. For the first round of coding, FS followed Open (or Initial) coding, ${ }^{14,15}$ characterized by "remaining open to all possible theoretical directions," of data analysis. For this stage of coding, we used Descriptive and In-Vivo codes, the latter meant to capture the data in the respondent's own words. ${ }^{15}$ Concurrent to coding and in accordance with best practices, ${ }^{15}$ detailed memos were kept recording coding decisions as well as questions, conflicts, and other thoughtprocesses that arose. For the second round of coding, both authors employed Focused Coding, searching the initial codes for those that were most salient ${ }^{14,15}$ and could be grouped into larger themes. Both authors met on a regular basis to reach consensus on the development of focused codes and themes. Memos relating to specific codes were revisited as an essential part of the focused coding process. Coding to consensus allowed for rich conversations regarding the data and prevented one author's narrative or interpretation of the data and codes to override that of the other.

\section{Results}

The majority of respondents identified ethnically as nonHispanic $(97.3 \%)$ and racially as white $(82.5 \%)$ followed by Asian $(6.7 \%)$. Because there were not enough data points from individuals from various ethnicities and races, we did not scrutinize the data for differences in experiences along racial and ethnic categorization. Of the 291 cases, 156 were women $(\sim 54 \%), 128$ were men $(\sim 44 \%)$ and seven either chose not to report gender or identified as other $(\sim 2 \%)$. Chi-square distribution tests were run to assess whether the distribution in the other demographic variables (Track, Rank, and Children) was statistically different from the expected distribution across binary gender. There were no statistically significant differences (Table 2). The largest faculty group of respondents ( $42.4 \%$ for men; $41.0 \%$ for women) were from the hybrid track, which represents $40 \%$ of the organization's faculty invited to participate in the study. At the organization, the percent faculty on the clinical track is $32 \%$ and $28 \%$ on the research track. Men and women were roughly evenly distributed across the three ranks of assistant, associate, and full tenured professor. $85.8 \%$ of male faculty and $86.3 \%$ of female faculty reported having children (Table 2).

\section{Quantitative}

\section{Binary Gender Differences of Faculty Experience}

Differences in the mean scale scores of the study variables between binary genders were examined by performing a series of $t$-tests. Male faculty reported statistically higher Role Certainty, Commitment to Organization, Commitment to Department, Support from Department, and Promotion Climate equity than did female faculty (Table 2). No statistical differences were found between male and female faculty for the outcome variables of Promotion Aspirations, Leadership Aspirations, and Intentions to Leave.

\section{Predictors for Promotion Aspirations (Table 3 and Supplementary Table 2)}

The variable groups added in Step 1 (Demographics), Step 4 (Organizational Commitment and Support), and Step 5 
Table 2 Descriptive Statistics - Variable Comparisons by Gender

\begin{tabular}{|c|c|c|c|c|c|c|c|c|c|}
\hline \multirow{3}{*}{$\begin{array}{l}\text { Demographics } \\
\text { Track }\end{array}$} & \multicolumn{4}{|c|}{ Men } & \multicolumn{4}{|c|}{ Women } & \multirow{3}{*}{$\begin{array}{l}\begin{array}{c}\text { Chi- } \\
\text { Square }^{\mathrm{a}}\end{array} \\
4.6 \\
\mathrm{p}=0.099\end{array}$} \\
\hline & \multirow{2}{*}{$\frac{\mathbf{n}}{128}$} & \multicolumn{3}{|c|}{ Category } & \multirow[b]{2}{*}{156} & \multicolumn{3}{|c|}{ Category } & \\
\hline & & Clin. $16.4 \%$ & Hyb. $42.4 \%$ & $\begin{array}{l}\text { Res. } \\
41.4 \%\end{array}$ & & Clin. $26.3 \%$ & Hyb. $41.0 \%$ & $\begin{array}{l}\text { Res. } \\
32.7 \%\end{array}$ & \\
\hline Rank & 128 & $\begin{array}{l}\text { Assist. } \\
34.4 \%\end{array}$ & $\begin{array}{l}\text { Assoc. } \\
28.1 \%\end{array}$ & Full $37.5 \%$ & 156 & $\begin{array}{l}\text { Assist. } \\
36.5 \%\end{array}$ & $\begin{array}{l}\text { Assoc. } \\
34.6 \%\end{array}$ & Full $28.8 \%$ & $\begin{array}{l}2.64 \\
p=0.268\end{array}$ \\
\hline Children & 127 & Yes $85.8 \%$ & No $14.2 \%$ & & 153 & Yes $86.3 \%$ & No $13.7 \%$ & & $\begin{array}{l}0.012 \\
p=0.914\end{array}$ \\
\hline \multirow{2}{*}{\multicolumn{3}{|c|}{ Mean Scale }} & \multicolumn{3}{|c|}{ Men } & \multicolumn{3}{|c|}{ Women } & T-Test ${ }^{b}$ \\
\hline & & & $\mathbf{n}$ & Mean & SD & $\mathbf{n}$ & Mean & SD & \\
\hline \multicolumn{3}{|l|}{ Role Certainty } & 128 & 4.19 & 0.67 & 156 & 3.93 & 0.81 & $\begin{array}{l}2.815 \\
p=0.005\end{array}$ \\
\hline \multicolumn{3}{|l|}{ Role Conflict } & 128 & 3.07 & 0.93 & 156 & 3.1 & 0.94 & -0.298 \\
\hline \multicolumn{3}{|l|}{ Role Overload } & 128 & 3.34 & 0.88 & 156 & 3.51 & 1 & -1.535 \\
\hline \multicolumn{3}{|c|}{ Multiple Role Flexibility } & 128 & 3.21 & 0.83 & 156 & 3.37 & 0.99 & -1.494 \\
\hline \multicolumn{3}{|c|}{ Work into Family Conflict } & 128 & 3.75 & 0.87 & 156 & 3.79 & 0.88 & -0.372 \\
\hline \multicolumn{3}{|c|}{ Family into Work Conflict } & 128 & 2.46 & 0.91 & 155 & 2.55 & 0.93 & -0.88 \\
\hline \multicolumn{3}{|c|}{ Commitment to Org. } & 128 & 3.19 & 0.94 & 156 & 2.91 & 0.83 & $\begin{array}{l}2.674 \\
p=0.008\end{array}$ \\
\hline \multicolumn{3}{|l|}{ Support from Org. } & 128 & 2.76 & 0.93 & 156 & 2.56 & 0.88 & 1.797 \\
\hline \multicolumn{3}{|c|}{ Commitment to Dept. } & 128 & 3.8 & 1.05 & 154 & 3.46 & 0.98 & $\begin{array}{l}2.829 \\
p=0.005\end{array}$ \\
\hline \multicolumn{3}{|c|}{ Support from Dept. } & 128 & 3.7 & 1.11 & 154 & 3.32 & 1.09 & $\begin{array}{l}2.914 \\
p=0.004\end{array}$ \\
\hline \multicolumn{3}{|c|}{ Promotion Climate } & III & 3.43 & 0.081 & 133 & 3.19 & 0.77 & $\begin{array}{l}2.455 \\
p=0.015\end{array}$ \\
\hline \multicolumn{3}{|c|}{ Leadership Aspirations } & 124 & 3.65 & 1.04 & 149 & 3.48 & 0.96 & 1.46 \\
\hline \multicolumn{3}{|c|}{ Promotion Aspirations } & 116 & 3.66 & 1.29 & 137 & 3.55 & 1.3 & 0.713 \\
\hline \multicolumn{3}{|c|}{ Intentions to Leave } & 128 & 1.59 & 0.67 & 156 & 1.46 & 0.58 & 1.754 \\
\hline
\end{tabular}

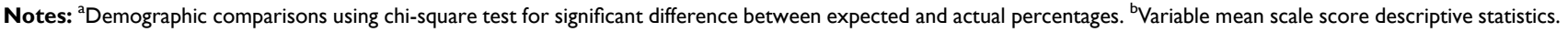
Two-way, unpaired t-tests assuming equal variance were used to compare population means between men and women. Bolded values have $p<0.05$.

Abbreviations: Clin, clinical track; Hyb, hybrid track; Res, research track; Assist, assistant professor; Assoc, associate professor; Full, full professor; SD, standard deviation.

(Departmental Commitment and Support) significantly increased the variance explained by the model. In the final model, which included all variables, Track, Rank, Role Certainty, Role Overload, Family Into Work, Commitment to Organization, and Support from Department were all significant factors in explaining the variance in promotion aspirations.

For the Demographic variables, the beta weight for Rank had a negative correlation with promotion aspirations; those who are at higher ranks have lower promotion aspirations. For the Role Strain variables, lower Role Certainty and higher Role Overload were associated with higher promotion aspirations. Of the Work/Family Conflict variables, only the Family into Work conflict variable was statistically significant and negatively associated with promotion aspirations, such that those with lower family into work conflict reported higher promotion aspirations. In the final model, 


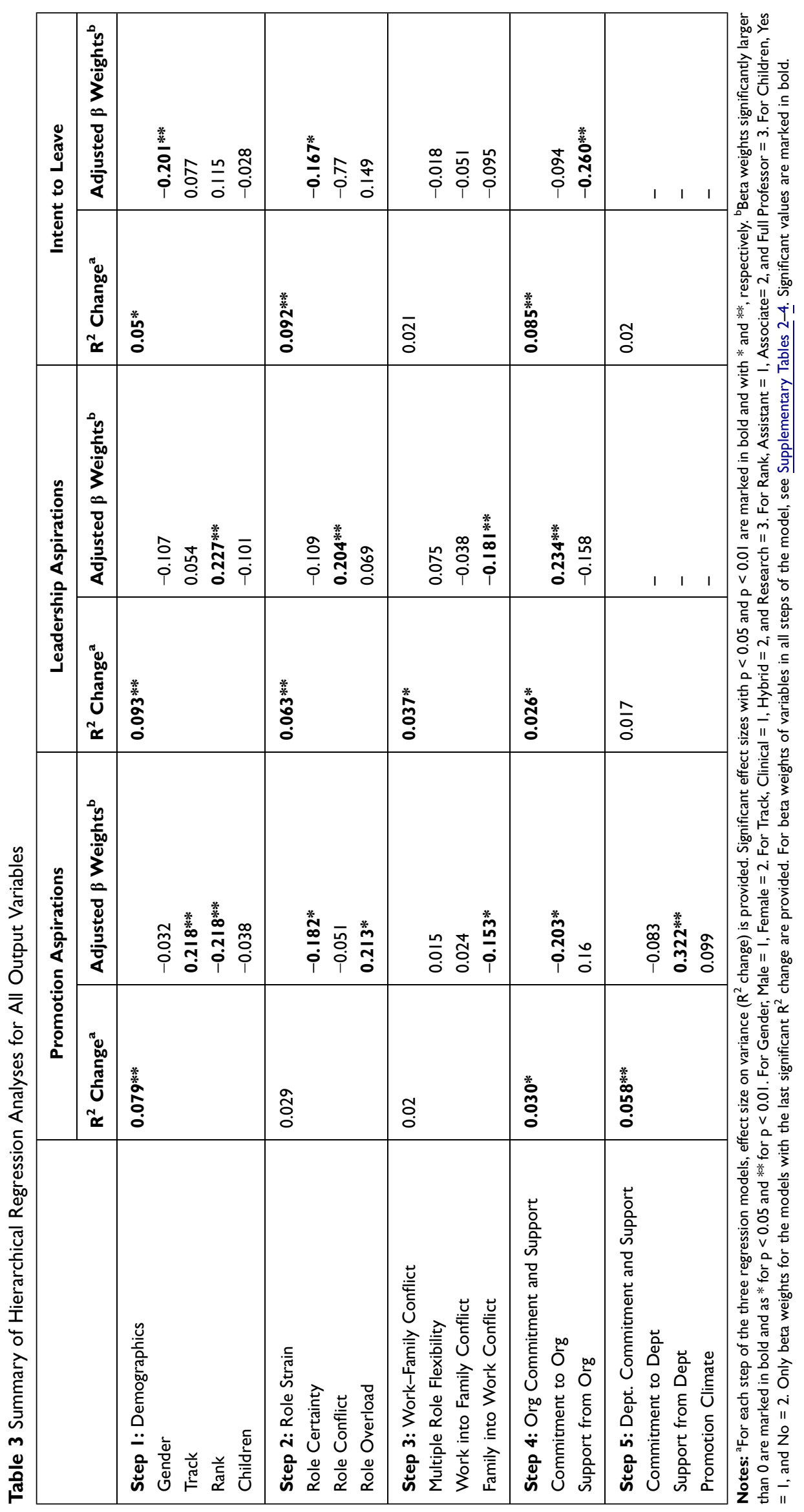


Commitment to the Organization and Support from the Department were significantly correlated with promotion aspirations. Variables in the final Promotion Aspirations regression model explained $15.5 \%$ of the variance.

\section{Predictors for Leadership Aspirations (Table 3 and Supplementary Table 3)}

The addition of variables at all steps except for Step 5 (Departmental Commitment and Support) accounted for statistically significant variance to the model. In the final statistically significant regression equation (Step 4), Rank, Role Conflict, Family Into Work, and Commitment to the Organization were all significant factors. Higher Rank was positively associated with leadership aspirations. Role Conflict was also positively associated with leadership aspirations. Lower levels of Family into Work conflict were associated with higher levels of leadership aspirations, again suggesting that faculty who perceive family life conflicting with their work life might be more reluctant to seek out leadership and the added burden that would come with it. This pattern was similar to the impact of Family into Work conflict for the Promotion Aspirations regression model. In the final model, Commitment to the Organization also significantly explained variance in leadership aspirations. In this case, higher levels of organizational commitment correspond to higher leadership aspirations. The final model at Step 4 explained 17.6\% of the variance in leadership aspirations.

\section{Predictors for Intentions to Leave (Table 3 and Supplementary Table 4)}

Variables in Step 1 (Demographics), Step 2 (Role Strain), and Step 4 (Organizational Commitment and Support) all significantly increased the explanation in variance in the Intentions to Leave regression model. In the final model, Gender is a significant variable, indicating female faculty respondents have lower intentions to leave than male faculty. High Role Certainty is associated with lower intentions to leave, as is high Support from Organization. This is different to the salience of Commitment to the Organization in the promotion and leadership models. The final regression model explained $20.9 \%$ of the variance in intentions to leave, and there were no significant interaction variables for gender with other variables in the model.

Out of all the variable groups, Organizational Commitment and Support (Step 4), was the only one that significantly increased the variance explained across all three regression models.
Table 4 Selected Quotes for Themes and Codes of Short Answer Responses for Questions Related to Promotion

\begin{tabular}{|c|c|c|}
\hline Theme & Code & Quote \\
\hline \multirow[t]{4}{*}{$\begin{array}{l}\text { Process: } \\
\text { Can } \\
\text { I Advance? }\end{array}$} & $\begin{array}{l}\text { Misaligned } \\
\text { Standards }\end{array}$ & $\begin{array}{l}\text { "In our department it is } \\
\text { impossible to be promoted to } \\
\text { full professor without } \\
\text { a 'national' reputation ..." }\end{array}$ \\
\hline & Satisfactory Process & $\begin{array}{l}\text { "I had unanimous support for } \\
\text { promotion from assistant to } \\
\text { associated (sic) professor } \\
\text { from my department." }\end{array}$ \\
\hline & $\begin{array}{l}\text { Unsatisfactory } \\
\text { Process - Unclear } \\
\text { Expectations }\end{array}$ & $\begin{array}{l}\text { "I have no clue what it would } \\
\text { take to advance to associate } \\
\text { professor in my department. } \\
\text { This has NEVER been spelled } \\
\text { out or made clear to those of } \\
\text { us on the clinical track." }\end{array}$ \\
\hline & $\begin{array}{l}\text { Limited } \\
\text { Opportunity }\end{array}$ & $\begin{array}{l}\text { "Not clear that there is much } \\
\text { opportunity for further } \\
\text { advancement." }\end{array}$ \\
\hline $\begin{array}{l}\text { Value: Do } \\
\text { I Want It? }\end{array}$ & $\begin{array}{l}\text { Lack of Value, } \\
\text { Compensation, or } \\
\text { Rewards }\end{array}$ & $\begin{array}{l}\text { "On the [hybrid] track, it } \\
\text { doesn't matter what } \\
\text { promotions you achieve - you } \\
\text { will never be considered to be } \\
\text { a full faculty member and your } \\
\text { salary won't change." }\end{array}$ \\
\hline $\begin{array}{l}\text { Guidance: } \\
\text { Am } \\
\text { I Supported? }\end{array}$ & $\begin{array}{l}\text { No Guidance, } \\
\text { Mentoring, or } \\
\text { Support }\end{array}$ & $\begin{array}{l}\text { "I was very poorly (ie, barely) } \\
\text { mentored regarding } \\
\text { promotion in my department." }\end{array}$ \\
\hline
\end{tabular}

\section{Qualitative}

\section{Themes for Promotion Aspirations (Table 4)}

Our thematic analyses revealed three key themes from participant responses: Process (Can I Advance?), Value (Do I Want It?), and Guidance (Am I Supported?).

The Process theme captures respondents' satisfaction or dissatisfaction with the promotion process itself. Faculty expressed frustrations that their day to day demands or career interests did not align with the requirements for promotion, thus making promotion either irrelevant or unattainable, and that the bureaucratic process of applying for promotion lacked clear expectations and transparency. Faculty also reported the overall lack of opportunities for promotion within their department and organization.

The Value theme encompasses respondents' comments regarding promotion not being valued or highly regarded by faculty themselves, whether due to a lack of interest in the increased role burden, or the lack of tangible rewards 
(eg, pay, increased administrative support, recognition) that it would bring. A few respondents also noted that in some cases, they had either been actively discouraged from seeking promotion, or that because promotion was never discussed within their departments, being promoted was perceived as not highly regarded by the organization and/or department.

Finally, the Guidance theme captures respondents' those codes in which respondents spoke of the mentoring they had received while making career advancement decisions, as well as the guidance they had received navigating the promotion process. While some respondents were pleased with the guidance and mentorship they had received in this area, the majority of comments centered around the lack of mentoring and guidance they had received.

\section{Themes for Leadership Aspirations (Table 5)}

Though many respondents commented that they were already in a leadership position or they were too early in their career to hold one, consistent with the rank variable in the regression model, three themes emerged: Process (Can I Advance?), and Value (Do I Want It, as with Promotion Aspirations), and Overburdened.

The Overburdened theme captures respondents' comments on balancing competing demands and work-family navigation (Table 5), consistent with the salience of the Role Conflict and Family Into Work variables in the Leadership regression model.

The Value theme for leadership aspirations encompassed respondents' feelings towards the lack of increased compensation, rewards, administrative support, or protected time provided with leadership, making such positions undesirable. Other codes captured respondents' lack of interest in leadership given that it did not align with their temperament or how they wished to spend time.

Finally, the Process theme speaks to perceived cronyism and transparency, as well as an unclear process by which leadership positions were allocated.

\section{Themes for Intentions to Leave (Table 6)}

Many survey respondents listed their family and the inertia it would take to move them to another city as one factor that kept them at the organization. Within that context, participant responses centered on four key themes as factors contributing to their intentions to leave: Overburdened, Infrastructure (Am I Supported?), Growth (Can I Advance?) and Value (Am I Compensated?).
Table 5 Selected Quotes for Themes and Codes of Short Answer Responses for Questions Related to Leadership

\begin{tabular}{|c|c|c|}
\hline Theme & Code & Quote \\
\hline \multirow[t]{2}{*}{$\begin{array}{l}\text { Career Stage/ } \\
\text { Track }\end{array}$} & $\begin{array}{l}\text { Already in } \\
\text { Leadership }\end{array}$ & "I am a departmental leader." \\
\hline & $\begin{array}{l}\text { Too Early in } \\
\text { Career }\end{array}$ & $\begin{array}{l}\text { "I need more time in my current } \\
\text { position." }\end{array}$ \\
\hline \multirow[t]{2}{*}{ Overburdened } & $\begin{array}{l}\text { Balancing } \\
\text { Competing } \\
\text { Demands }\end{array}$ & $\begin{array}{l}\text { "While I think I could function in } \\
\text { a leadership role, I would rather } \\
\text { build my research independence, } \\
\text { and I cannot do both of those } \\
\text { things successfully while still being } \\
\text { clinically productive as well." }\end{array}$ \\
\hline & $\begin{array}{l}\text { Work-Family } \\
\text { Balance }\end{array}$ & $\begin{array}{l}\text { "Leadership position would have } \\
\text { impacted time available for } \\
\text { research and family." }\end{array}$ \\
\hline \multirow[t]{2}{*}{$\begin{array}{l}\text { Process: Can } \\
\text { I Advance? }\end{array}$} & Cronyism & $\begin{array}{l}\text { "Leadership positions are base } \\
\text { (sic) on buddy buddy and gender." }\end{array}$ \\
\hline & $\begin{array}{l}\text { Unclear } \\
\text { Hierarchy and } \\
\text { Process }\end{array}$ & $\begin{array}{l}\text { "Leadership roles are not clearly } \\
\text { or officially defined, meaning that } \\
\text { leaders are known de facto } \\
\text { rather than in title." }\end{array}$ \\
\hline \multirow[t]{2}{*}{$\begin{array}{l}\text { Value: Do } \\
\text { I Want It? }\end{array}$} & $\begin{array}{l}\text { No Incentives/ } \\
\text { Compensation }\end{array}$ & $\begin{array}{l}\text { "Many of the leadership roles } \\
\text { appear to involve taking on } \\
\text { a great deal of uncompensated } \\
\text { responsibility. By uncompensated, } \\
\text { I mean both time and money. } \\
\text { While I would enjoy a larger } \\
\text { 'voice' I am not sure that the } \\
\text { trade-off would be worth it." }\end{array}$ \\
\hline & $\begin{array}{l}\text { Leadership } \\
\text { Undesirable }\end{array}$ & $\begin{array}{l}\text { "I enjoy my clinical practice and } \\
\text { wouldn't want to be stuck in } \\
\text { meetings and on committees } \\
\text { all day." }\end{array}$ \\
\hline
\end{tabular}

Demanding Workload and Work Family Balance were grouped into an Overburdened theme. Infrastructure: Am I Supported referred to respondents receiving support for doing one's work. Two major codes under this theme were understaffing and under-compensation of support staff who handle administrative tasks, preventing clinical and research faculty from spending the majority of their efforts in their desired roles. Other infrastructure codes focused on workflow and infrastructure related to patient records for clinical faculty, and IRB tasks and grant-writing support for research faculty.

The theme, Growth: Can I Advance?, captured faculty perceptions of their opportunity to advance their career and explore interests beyond their work as clinicians and 
Table 6 Selected Quotes for Themes and Codes of Short Answer Responses for Questions Related to Intentions to Leave

\begin{tabular}{|c|c|c|}
\hline Theme & Code & Quote \\
\hline \multirow[t]{2}{*}{$\begin{array}{l}\text { Infrastructure: } \\
\text { Am } \\
\text { I supported? }\end{array}$} & $\begin{array}{l}\text { Understaffing } \\
\text { and Under- } \\
\text { compensation }\end{array}$ & $\begin{array}{l}\text { "More nurses, physician } \\
\text { assistants, administrative } \\
\text { assistants to improve patient } \\
\text { case" }\end{array}$ \\
\hline & $\begin{array}{l}\text { Infrastructure } \\
\text { and Workflow }\end{array}$ & $\begin{array}{l}\text { "Bring the workflow into the } \\
2 \mathrm{I}^{\text {st }} \text { century." }\end{array}$ \\
\hline \multirow[t]{2}{*}{$\begin{array}{l}\text { Value: Am } \\
\text { I Compensated }\end{array}$} & $\begin{array}{l}\text { Salary and } \\
\text { Funding }\end{array}$ & $\begin{array}{l}\text { "If outside offers could } \\
\text { demonstrate additional } \\
\text { support for my research } \\
\text { (either from clinical/ } \\
\text { translational point of view, or } \\
\text { in dollars), and give me a salary } \\
\text { increase." }\end{array}$ \\
\hline & $\begin{array}{l}\text { Work and } \\
\text { Reward } \\
\text { Misalignment }\end{array}$ & $\begin{array}{l}\text { "If I felt more rewarded for the } \\
\text { efforts that I do put in - not so } \\
\text { much money-wise, though } \\
\text { I would like to be able to be } \\
\text { paid a fair wage for what I do." }\end{array}$ \\
\hline \multirow[t]{2}{*}{$\begin{array}{l}\text { Growth: Can } \\
\text { I Advance? }\end{array}$} & $\begin{array}{l}\text { Advancement } \\
\text { Opportunities }\end{array}$ & $\begin{array}{l}\text { "If [hybrid] track MDs are } \\
\text { given the support needed for } \\
\text { promotion I would certainly } \\
\text { stay." }\end{array}$ \\
\hline & $\begin{array}{l}\text { Opportunities } \\
\text { to Explore } \\
\text { Interests }\end{array}$ & $\begin{array}{l}\text { "I would appreciate being } \\
\text { offered protected time to } \\
\text { pursue ongoing efforts in } \\
\text { diversity and equity and } \\
\text { original community-engaged } \\
\text { work." }\end{array}$ \\
\hline \multirow[t]{2}{*}{ Overburdened } & $\begin{array}{l}\text { Demanding } \\
\text { Workload }\end{array}$ & $\begin{array}{l}\text { "The workload it (sic) way too } \\
\text { much to expect of anyone." }\end{array}$ \\
\hline & $\begin{array}{l}\text { Work-Family } \\
\text { Balance }\end{array}$ & $\begin{array}{l}\text { "Academic/nonclinical time } \\
\text { offers greater flexibility than } \\
\text { a } 100 \% \text { clinical job in private } \\
\text { practice, ie I can take my kids } \\
\text { to school once per week, etc." }\end{array}$ \\
\hline
\end{tabular}

researchers. This finding raises the importance of professional growth opportunities for faculty retention. The final theme, Value: Am I Compensated? Related to both respondents' salaries and what they could potentially earn at other research universities or in industry. This theme also captured sentiments about whether or not they felt their salary was commensurate with the work they performed and equitable to what their colleagues earned. We note that respondents' comments emphasized compensation as a proxy for being appreciated and valued by the organization.

\section{Discussion}

The purpose of the present study was to identify factors that contribute to aspirational and attrition-related career intentions of academic medical faculty. The results of our multivariate analysis indicate that different factors matter in the promotion aspirations, leadership aspirations, and intentions to leave of faculty in academic medicine. Family into Work conflict, for example, was statistically significant in the final regression model for Promotion and Leadership Aspirations, but not for Intentions to Leave. Role Certainty, on the other hand, was significant in faculty's promotion aspirations and intentions to leave, but not in their leadership aspirations, where Role Conflict was a larger factor. Overall, on-the-job factors (eg, Role Strain, Organizational Commitment and Support) were comparatively more significant than offthe-job factors and individual difference variables (eg, Work-Family Conflict, Rank) in the study outcomes.

Organizational Commitment and Support, which contained variables measuring faculty commitment to their organization, and their perceptions of support from their organization, respectively, was statistically significant across all three models. For both Promotion and Leadership Aspirations, it was the Commitment to the Organization variable within this step that had a significant beta weight in the model, while for Intentions to Leave, it was the Support from Organization. Our findings illustrate that bi-directional support from and commitment to the organization are drivers of faculty career intentions of faculty. Since this survey was conducted, the impact of organizational factors on individuals has become even more salient given the impact of COVID-19 on the workplace. Furloughs, compromised productivity, blurred boundaries between work and home, and worries over the health of family members have left many individuals struggling at work. ${ }^{16,17}$ Although it is tempting to implement individual-level solutions like wellness workshops, what is needed are system-level strategies to demonstrate organizational commitment and support to faculty, with the organization sharing the responsibility for promoting their engagement. $^{1}$

Our qualitative analysis of the short answer responses related to the organizational commitment and support variables revealed a disconnect between the Can I Advance, Do I Want It themes in promotion and leadership questions and the Can I Grow, Am I Valued themes in the intentions to leave questions. That is, there is incongruence between 
faculty's desire for advancement and the availability of advancement opportunities that are satisfying and meaningful to faculty. Academic medical centers may facilitate faculty growth through offerings like formal mentoring for career and leadership development and executive coaching to help faculty strategize their desired career advancement. Indeed, Zimmerman et $\mathrm{al}^{18}$ found that receiving professional development opportunities, appreciation from supervisors, or a daily sense of accomplishment were key factors in faculty engagement. But, ultimately the impact of organizational efforts is only as effective as their alignment with the values of the faculty. Alignment of individual and institutional values as well as management of career-life choices are strong predictors of academic medical faculty vitality. ${ }^{2,19}$ Monitoring the effectiveness of faculty talent development investments by collecting evaluation data on those investments will allow for institutional accountability in ensuring effective actions aligned with faculty values.

The salience of Role Strain variables (ie, role certainty, role conflict) in all of our study's models points to the need for academic medical centers to better align faculty job expectations and needed support to fulfill job duties. Our qualitative analysis of short answer data demonstrates that providing adequate staff and protected time to explore other interests that benefit the organization, such as community outreach or anti-racism work, and having clear and transparent promotion and leadership processes, are critical. Wai et $\mathrm{al}^{20}$ found that although salary and benefits were important to academic physicians' workplace satisfaction and retention, factors like collegiality, time spent on mission areas, and autonomy were more important and suggest areas ripe for organizational commitment efforts.

\section{Limitations}

We employed a cross-sectional research design at a single academic institution. Longitudinal studies are needed to establish causation and additional work at other institutions will broaden the generalizability of our results. Because of the high inter-correlation among the Organizational Support and Organizational Commitment variables, future studies may conduct factor analyses on these scales and create latent variables to further assess which aspects of these best relate to promotion aspirations. Senior faculty (ie, department chairs, division leaders) were challenged in how to respond to the short answer questions for leadership or promotion aspirations given their advanced status. Twelve senior faculty indicated that the questions were irrelevant to them, with some noting that they had responded retroactively, thinking back to when promotion and leadership opportunities were still available to them. Future surveys using turnover theory should take this into account, given that many of the scales we used were developed and validated in occupational settings where more promotion and leadership opportunities are available to employees. Our response rate of $25 \%$ is another study limitation. Although simulation studies have found that for surveys with 205 to 399 respondents, the results of a response rate of $25 \%$ or higher of the sample had a $95 \%$ correlation to the results of analysis done with a full sample, ${ }^{21}$ higher response rates can yield richer data sets for mining both quantitatively and qualitatively. Finally, given the disparate rates of promotion, leadership, and attrition for faculty from underrepresented racial and ethnic (UR) groups, ${ }^{22}$ future studies should target a larger sample size of UR academic medical faculty to investigate correlates of their aspirational and attrition-related career intentions.

\section{Conclusion}

Advancing organizational policy that supports infrastructure for evidence-based interventions and programming for the intentional career development of faculty is an important aspect of a proactive talent development and retention model in academic medical centers. We encourage leadership to be intentional in enacting efforts that demonstrate the organizations' commitment to faculty, grounded in their needs and values.

\section{Ethical Approval}

The authors received approval from the UW-Madison Education and Social Behavioral Science Institutional Review Board (protocols \#2014-1583, \#2019-0590). All survey participants gave their informed consent before completing the survey and actively consented to have aggregate data, including anonymized responses, shared in reports. The study was conducted in accordance with The Declaration of Helsinki: every precaution was taken to protect the privacy of the research subjects and confidentiality of their personal information.

\section{Acknowledgments}

The authors thank Dr. Mark Connolly for his guidance, support, and mentoring during qualitative analysis and Dr. Stephanie Budge for her guidance, support, and suggestions for the quantitative analysis. 


\section{Funding}

No direct funding was received to conduct the study. Support for salary (FS and ABW) and for publication fees was provided by the Collaborative Center for Health Equity (UW Foundation fund \#233-AAI7362-532901). Additional salary support for ABW was provided by the Department of Medicine at the University of Wisconsin Madison.

\section{Disclosure}

The authors report no conflicts of interest in this work.

\section{References}

1. Shanafelt T, Noseworthy H. Executive leadership and physician well-being: nine organizational strategies to promote engagement and reduce burnout. Mayo Fndn Med Ed Res. 2017;92(1):129-146.

2. Pololi L, Evans A, Civian J, et al. Faculty vitality-surviving the challenges facing academic health centers. Acad Med. 2015;90 (7):930-936. doi:10.1097/ACM.0000000000000674

3. Dandar VM, Field JP, Garrison GF. Promising Practices for Promoting Faculty Engagement and Retention at US Medical Schools. 2nd ed. Assn of Amer Medical Colleges; 2017. Available from: https://www. aamc.org/download/482128/data/promisingpracticespublication.pdf. Accessed September 10, 2020.

4. Maertz C, Griffeth R. Eight motivational forces and voluntary turnover: a theoretical synthesis with implications for research. J Manage. 2004;30:667-683.

5. Hom P, Lee TW, Shaw JD, Hausknecht JP. One hundred years of employee turnover theory and research. J Appl Psychol. 2017;102 (3):530-545. doi:10.1037/ap10000103

6. Holtom B, Inderrieden E. Integrating the unfolding model and job embeddedness order to better understand voluntary turnover. J Manag Issues. 2006;18:435-452.

7. Frone M, Russell M, Cooper M. Antecedents and outcomes of workfamily conflict: testing a model of the work-family interface. $J \mathrm{Appl}$ Psychol. 1992;77(1):65-78. doi:10.1037/0021-9010.77.1.65

8. Mody L, Griffith K, Jones R, et al. Gender differences in work-family conflict experiences of faculty in academic medicine. $J$ Gen Intern Med. 2021. doi:10.1007/s11606-020-06559-7

9. Ellinas E, Fouad N, Byars-Winston A. Women and the decision to leave, linger, or lean in: predictors of intent to leave and aspirations to leadership and advancement in academic medicine. $J$ Womens Health. 2018;27(3):324-332. doi:10.1089/jwh.2017.6457
10. Creswell J, Plano Clark V. Core Mixed Methods Designs. Designing and Conducting Mixed Methods Research. 3rd ed. Thousand Oaks, CA: Sage Publications; 2018:51-99.

11. Fox M, Fonseca C, Bao J. Work and family conflict in academic science: patterns and predictors among women and men in research universities. Soc Stud Sci. 2011;41(5):715-735. doi:10.1177/ 0306312711417730

12. Tabachnick BG, Fidell LS. Using Multivariate Statistics. 6th ed. Pearson; 2012.

13. Ghasemi A, Zahediasl S. Normality tests for statistical analysis: a guide for non-statisticians. Int J Endocrinol Metab. 2012;10 (2):486-489. doi:10.5812/ijem.3505

14. Charmaz K. Coding in grounded theory practice. In: Constructing Grounded Theory: A Practical Guide Through Qualitative Analysis. Thousand Oaks, CA: Sage Publications Ltd; 2006:42-71.

15. Saldaña J. The Coding Manual for Qualitative Researchers. 3rd ed. Thousand Oaks, CA: Sage Publications Ltd.; 2009.

16. McGurtie B. The pandemic is dragging on: professors are burning out. The Chronicle of Higher Education; November 5, 2020. Available from: https://www.chronicle.com/article/the-pandemic-isdragging-on-professors-are-burning-out?cid=gen_sign_in. Accessed January 11, 2021.

17. Madsen TE, Dobiesz V, Das D, et al. Unique risks and solutions for equitable advancement during the COVID-19 pandemic: early experience from frontline physicians in academic medicine. NEJM Catal Innovations Care Delivery. 2020;1(4). Available from: https://catalyst.nejm.org/doi/full/10.1056/CAT.20.0268. Accessed November 5, 2021.

18. Zimmermann EM, Mramba LK, Gregoire H, Dandar V, Limacher MC, Good ML. Characteristics of faculty at risk of leaving their medical schools: an analysis of the StandPoint ${ }^{\mathrm{TM}}$ faculty engagement survey. $J$ Healthc Leadersh. 2020;12:1-10. doi:10.2147/JHL.S225291

19. Dankoski ME, Palmer MM, Nelson Laird TF, Ribera AK, Bogdewic SP. An expanded model of faculty vitality in academic medicine. Adv Health Sci Educ Theory Pract. 2012;17:633-649. doi:10.1007/s10459-011-9339-7

20. Wai P, Dandar V, Radosevich DM, Brubaker L, Kuo PC. Engagement, workplace satisfaction, and retention of surgical specialists in academic medicine in the United States. $J$ Am Coll Surg. 2014;219(1):31-42. doi:10.1016/j.jamcollsurg.2014.03.027

21. Fosnacht K, Sarraf S, Howe E, Peck LK. How important are high response rates for college surveys? Rev High Ed. 2017;40 (2):245-265. doi:10.1353/rhe.2017.0003

22. Washington D, Paasche-Orlow M, Liebschutz J. Promoting progress or propagating problems: strategic plans and the advancement of academic faculty diversity in U.S. medical schools. $J$ Natl Med Assoc. 2017;109(2):72-78. doi:10.1016/j.jnma.2016.10.001
Journal of Healthcare Leadership

\section{Publish your work in this journal}

The Journal of Healthcare Leadership is an international, peer-reviewed, open access journal focusing on leadership for the health profession. The journal is committed to the rapid publication of research focusing on but not limited to: Healthcare policy and law;Theoretical and practical aspects healthcare delivery; Interactions between healthcare and society and evidence-based practices; Interdisciplinary decision-making;
Philosophical and ethical issues; Hazard management; Research and opinion for health leadership; Leadership assessment. The manuscript management system is completely online and includes a very quick and fair peer-review system. Visit http://www.dovepress.com/ testimonials.php to read real quotes from published authors. 